\title{
Costumik Cosplay Alternative for Cosplay Lovers Tokusatsu and Indonesian Comic
}

\author{
Esin Sintawati, Maulyda Agustine, Dwi Rahayu Ningsih, Kana Fitrotul Hasuna Jazula \\ Enginering Faculty \\ Universitas Negeri Malang \\ Malang, Indonesia \\ esin.sintawati.ft@um.ac.id
}

\begin{abstract}
The number of cosplay and Tokosatsu lover has an enormous proportion in Indonesia. For attracting inhabitant of Indonesia, researchers try to make cosplay by applying unsure and culture of Indonesia. Cosplay will be produced that is still modern and will be suitable with character and cast of Tokosatsu and Indonesian comic. For example, fantasy comic Garudayana and the populer Tokosatsu film titled Bima Ksatria Garuda. Adding Indonesian unsure, researchers use lurik in the clothing design as the main material. Lurik is the one of Indonesian traditional material having line pattern with different colour of fiber.
\end{abstract}

Keywords_cosplay; tokusatsu; lurik; comic

\section{INTRODUCTION}

Cosplay is a hobby of wearing clothing along with accessories and makeup as worn by characters in anime, manga (comics), fairy tales, video games, idol singers and musicians, as well as cartoons. Japanese cosplay which represents Japanese culture is very popular in Indonesian society, especially youth generation. It is proven from huge number of cosplay community such as Aeon Cosplay Team, Albatross Force, Amanogawa J Community, Baka Hito, Cosuki, Cosmo, Cosura, Dokuritsu, Hikari and many more. The word cosplay comes from "costume" and "play" which means cosplayer (the one who cosplays) intimate characters' look of Tokusatsu film, comic, and video games. It includes their wardrobe, make up, accessories, and other properties to animate their characters. There is a pro and contra of this culture which says that by cosplay Japanese characters Indonesian youth do not embrace their own culture. However Indonesia has its great Tokusatsu and comic which possible to be cosplayed such as Garudayana, Marcapada, Nusantara Warriors, Jaka Kaharuan, Si Juki, Si Gundul, and Tokusatsu film entitled Bima Ksatria Garuda [1]. In fact, cosplay is not always about Japanese. It can be inspired from original characters, too. Invention relates to the making of the original design of cosplay fashion by using the main material lurik as an application of science in the field of fashion, especially design. The design is intended for the introduction of the use of lurik fabrics and cosplay
Indonesian characters on cosplayer Indonesia. Inspiraton for cosplay fashion design lifted from tokusatsu film and comic Indonesia, that is Bima Ksatria Garuda and Komik Garudayana.

Therefore, to attract Indonesian youth of the Indonesianbased characters cosplay, the proposer creates cosplay based on Indonesian culture. It creates with a fresh design and appropriate Indonesian characters without omitting real cosplay outline. The inspiration of this cosplay comes from Garudayana and Ksatria Garuda. Then, to strengthen the Indonesian unsure, the proposer uses Lurik. It is a traditional Indonesian fabric with has line pattern with different fiber colors. It was a traditional sacral fabric which only used to religious ceremony [2]. Nowadays, by the developing of Indonesian fashion mode, the beauty and its uniqueness of the Lurik may be combined to unlimited variation.

This production is aimed to increase the selling value of the Lurik, create Indonesian cosplay identity with a fresh design which appropriates with Indonesian Tokusatsu and comic, to make youth love Indonesian culture and to promote Lurik in international. Then, this cosplay is called Costumik because it uses Indonesian culture as base inspiration. Costumik gives innovation and solution to the Indonesian cosplayers so they still can cosplay with Indonesian culture as the content instead of Japanese. Then, the proposer expects that this kind of new cosplay can offer the beauty of Lurik becomes trendsetter in Indonesia and international [3].

\section{METHODS}

\section{A. Preparation of Production}

In pre-production stage there are some process required such as make product design, analyze the costumer interest, select materials as the main material is Lurik, The costumer interest analyzing is aimed to discover costumer interest so it can be applied in cosplay design. 


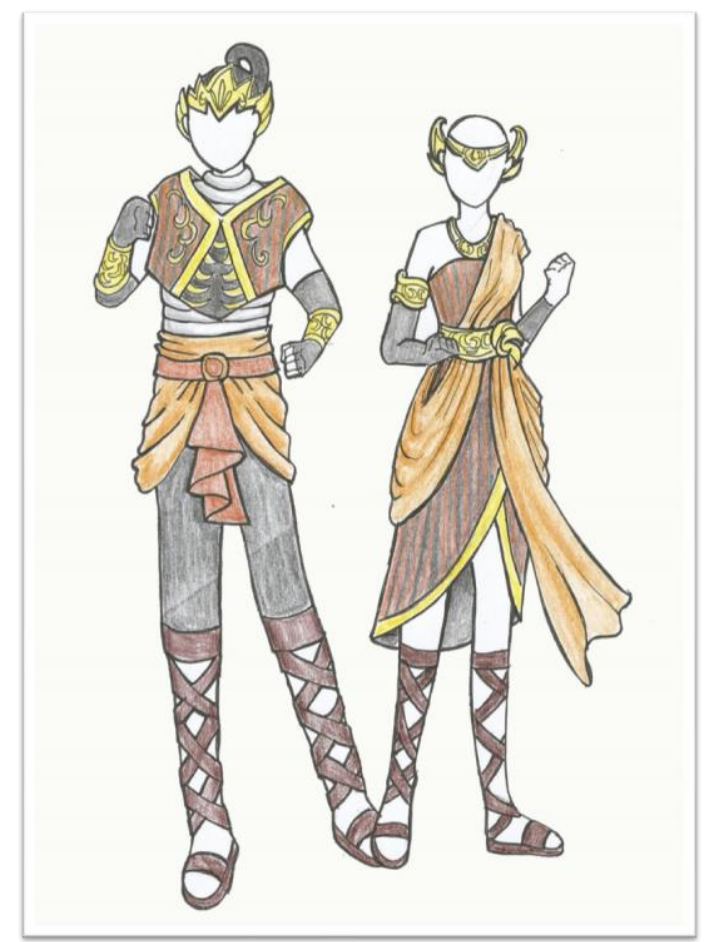

Fig.1: cosplay comic design

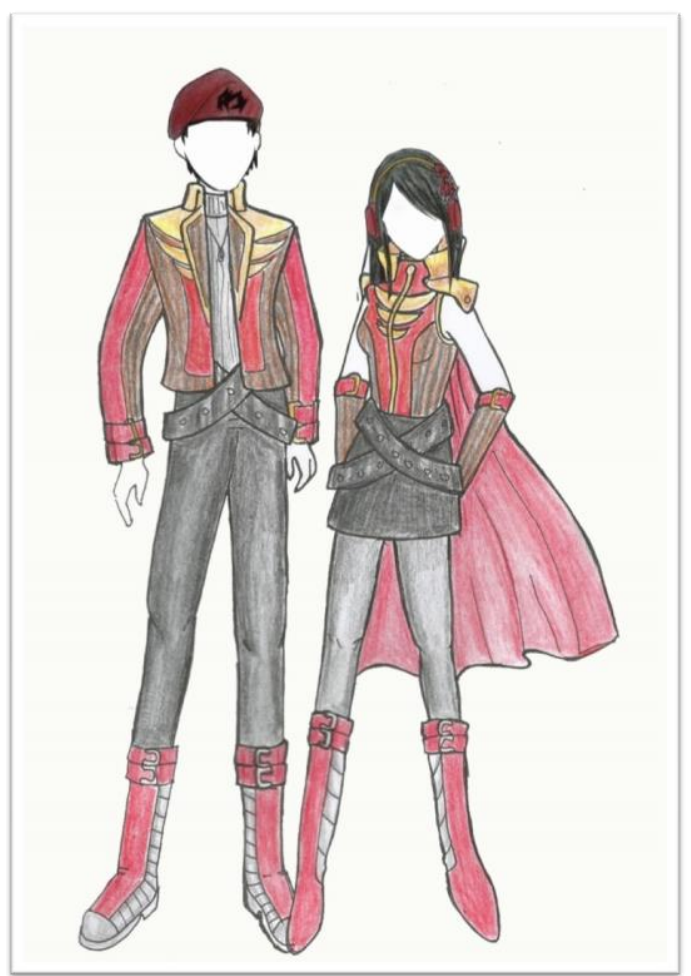

Fig 2: cosplay tokusatsu design

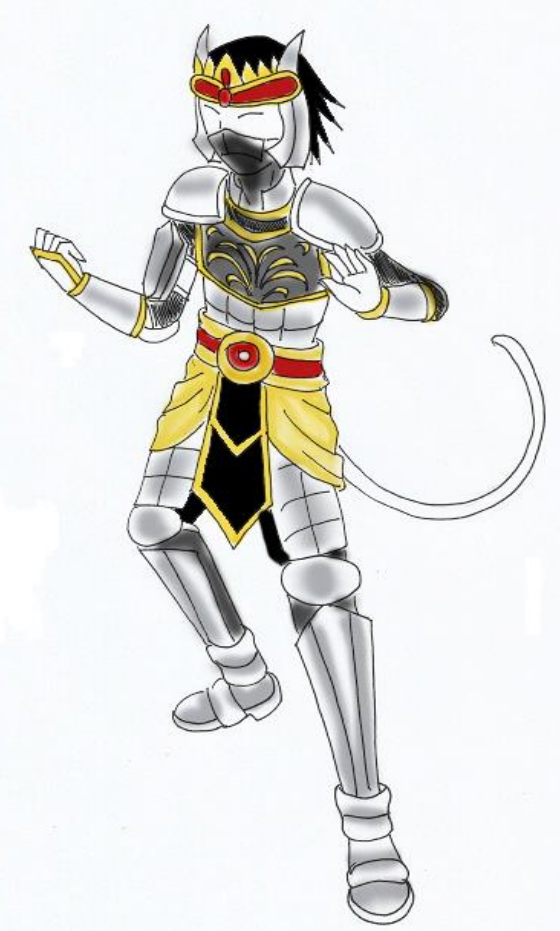

Fig 3: cosplay Hanoman design

\section{B. Production}

In this stage the processes are pattern making, cutting, sewing, accessorizing, finishing, and quality control.

\section{Marketing}

The product is marketed by online and offline marketing system. The online marketing is using door-to-door system in some cosplay communities in some events such as Comicamp 2017, J-Coshokai, East and West, J-Sphere while the online is marketed through social media such as Facebook, Instagram, and BBM.

\section{Periodic Evaluation}

After doing all the process, it is necessary to do periodic evaluation to know the achievement target that has been accomplished those which has not accomplished by the Costumik. The evaluation is included marketing, quality of the product, improve the quality of the product, and analyze costumer testimony. Besides, this kind of evaluation is useful to increase the Costumik performance.

\section{FINDINGS AND DISCUSSION}

Costumik is one type of a business focus on Indonesian Cosplay production. Actually there are similar types of garment industry that expose Indonesian culture of its branding. Yet, to compete it, Costumik has its own 
innovative and unique cosplay design, marketing system, and production. The advantages of this product are (1) Original, personal work without cheating of any resources, (2) Represent original character of Indonesian comic and tokusatsu film, (3) Use Lurik, as the original traditional fabric of Indonesia, (4) The price is appropriate based on the product quality. Then, the positive responds of people toward brand-new products show that Costumik has great opportunity to grow in this industry field.

The marketing of the product is using online and offline system. The offline is using door-to-door marketing system in some cosplay communities in some events such as Comicamp 2017 in Mall Dinoyo Malang, J-Coshokai in Politeknik Negeri Malang, dan East and West in Universitas Merdeka Malang while the online is marketed through social media such as Facebook, Instagram, and BBM.

Costume is well known by cosplayer, it is proved by many prospective customers who contact the marketing because they are interested in cosplay maker, some are also interested to order accessories. In the matter of the craftsmen who made accessories already have a suitable partner so they can accept the accessories order with certainty. Other results obtained are the output of scientific articles have been achieved and registration for the patent has been implemented.

\section{A. BEP Analysis}

$\mathrm{BEP}=$ investment / contribution margin per month $=3.747 .917 / 1.325 .775$

$=2.83$ (rounded to 3 months)

The above calculation uses the average April-May sales of 6.5 units per month, BEP will be obtained in the third month.

Thus, $2.83 / 3 \times(6.5 \times 3)=0.9433 \times 19.5$

$=18.394$ rounded to 18.4

It takes 19 units to sell the BEP

\section{B. Sales}

Cosplay production in April to June costumik managed to sell 22 sets of costumes. With sales details as follows.

TABLE 1. TABLE OF SALES AND PROFITS COSTUMIK PRODUCTS

\begin{tabular}{|l|l|l|l|l|}
\hline Month & $\begin{array}{c}\text { Product } \\
\text { Type } \\
\text { Sold }\end{array}$ & Total & $\begin{array}{c}\text { Amount } \\
\text { Selling Price }\end{array}$ & $\begin{array}{c}\text { Contribution } \\
\text { Margin }\end{array}$ \\
\hline April & Product A & 1 Set & Rp. 550.000 & Rp. 187.950 \\
$\mathbf{2 0 1 7}$ & Product B & 1 Set & Rp. 550.000 & Rp. 180.750 \\
& Product C & 1 Set & Rp. 550.000 & Rp. 219.750 \\
& Product D & 1 Set & Rp. 550.000 & Rp. 219.750 \\
\hline
\end{tabular}

\begin{tabular}{|l|l|l|l|l|}
\hline Month & $\begin{array}{c}\text { Product } \\
\text { Type } \\
\text { Sold }\end{array}$ & Total & \multicolumn{1}{|c|}{$\begin{array}{c}\text { Amount } \\
\text { Selling Price }\end{array}$} & $\begin{array}{c}\text { Contribution } \\
\text { Margin }\end{array}$ \\
\hline May & Product A & 3 Set & Rp. 1.650.000 & Rp. 563.850 \\
$\mathbf{2 0 1 7}$ & Product B & 1 Set & Rp. 550.000 & Rp. 180.750 \\
& Product C & 2 Set & Rp. 1.100.000 & Rp. 439.500 \\
& Product D & 3 Set & Rp. 1.650.000 & Rp. 659.250 \\
\hline June & Product A & 2 Set & Rp. 1.100.000 & Rp. 375.900 \\
$\mathbf{2 0 1 7}$ & Product B & 1 Set & Rp. 550.000 & Rp. 180.750 \\
& Product C & 3 Set & Rp. 1.650.000 & Rp. 659.250 \\
& Product D & 3 Set & Rp. 1.650.000 & Rp. 659.250 \\
\hline Total & & 22 set & Rp. 12.100.000 & Rp. 4.527.200 \\
\hline
\end{tabular}

Information:

Product A: cosplay garudayana female (kinara)

Product B: cosplay garudayana male (gatotkaca)

Product C: cosplay bimaksatria garuda female

Product D: cosplay bimaksatria garuda male

Based on the table is obtained sales chart below:

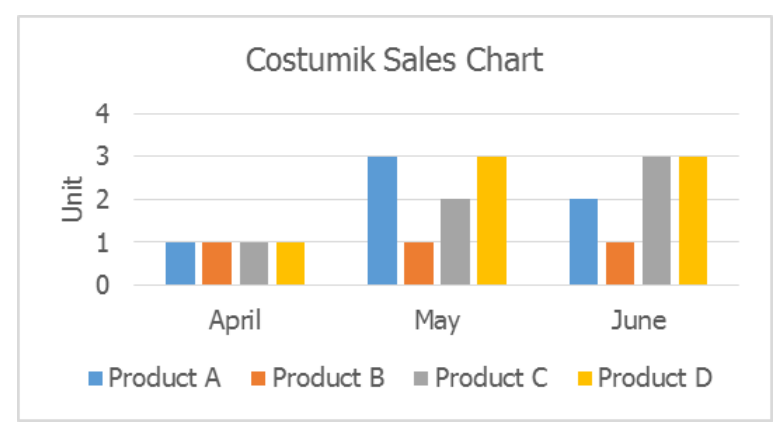

Fig. 4. Sales Chart of Costumik Product

Based on the chart above, it can be concluded that the selling of the product is increasing from April that can sell 4 set of costumes, May can sell 9 sets of costumes, and June can sell 9 sets of costumes. Graph shows that in the 3rd month (June) the sale of Costumik has reached BEP.

\section{Photo and sales documentation}

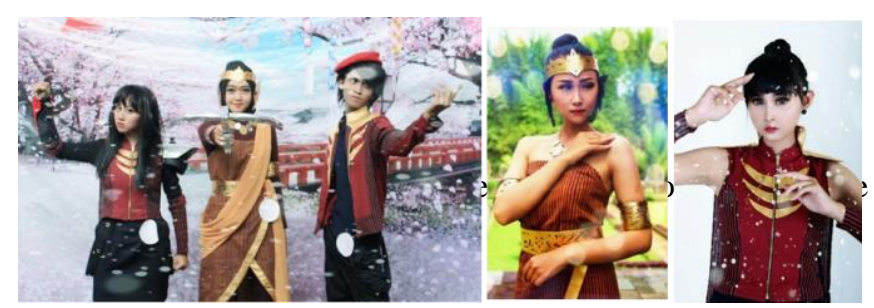

Fig. 5. Documentation of coswalk of J-Chosokai 2 event at Dinoyo Mall Malang 


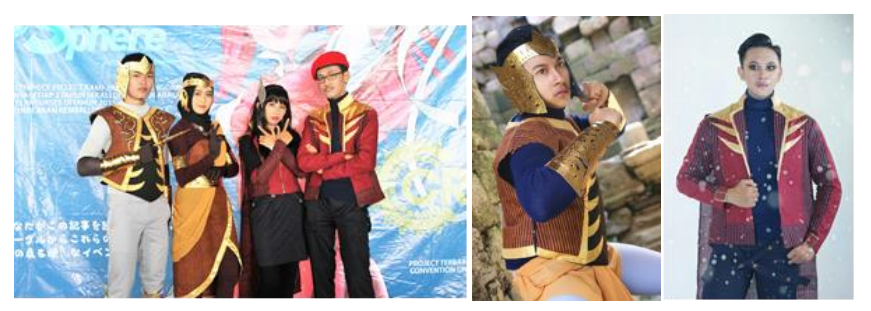

Fig. 6. Documentation of costreet of Comicamp 2 event at Dinoyo Mall Malang

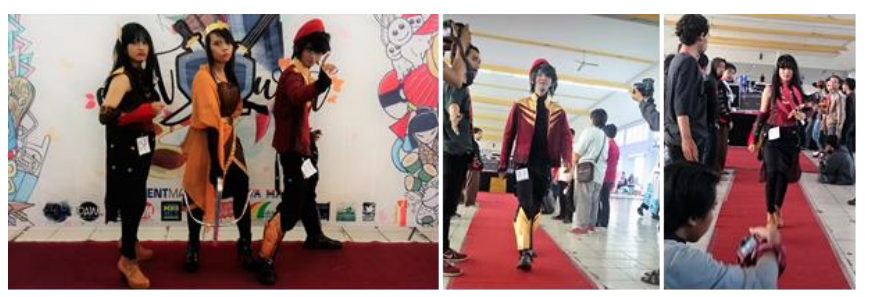

Fig. 7. Documentation of cosplay parade of East and West event at Universitas Merdeka Malang

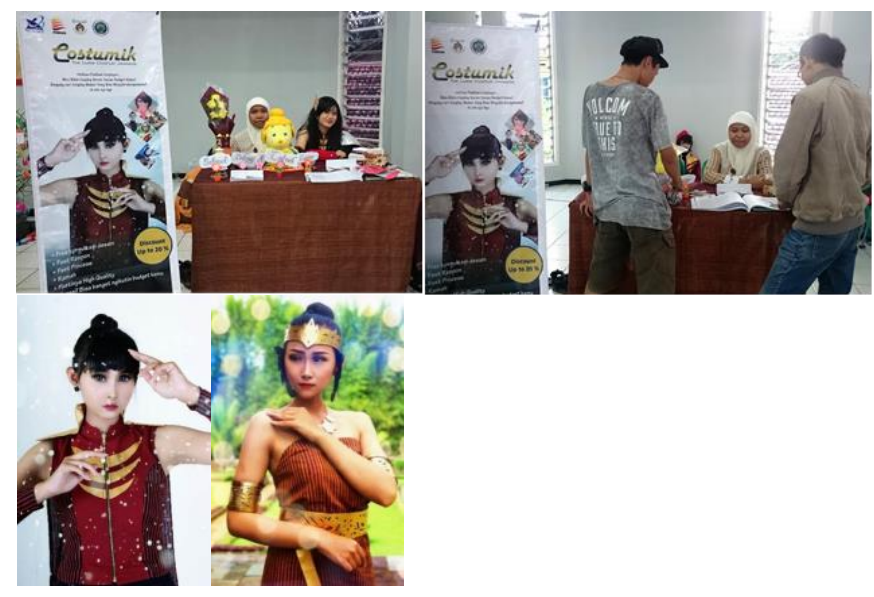

Fig. 8. Documentation of open booth at East and West event of Universitas Merdeka Malang

\section{CONCLUSION}

From the findings and discussion above it can be concluded that cosplayer and the event organizer are positively respond to the Costumik products because this kind of product enrich the cosplay variation. Beside, this new-brand product is opening a new business opportunity for the college students. The proposer hopes that by producing Costumik, youth generation embraces their culture.

\section{ACKNOWLEDGMENT}

During the process of this Grant Student Creatifity Program, the proposer got many material and spirituals helps and guidance from many parties. Because of those helps, we would like to thanks: (1) Ministry of research, technology, and education for the funding of this program, (2) Dr. Syamsul Hadi, M.Pd., M.Ed. of the Vice Rector III State University of Malang, 3) Prof. Dr. Marji, M. Kes, Vice Dean III Faculty of Technique, 4) Dra. Esin Sintawati, M. Pd. as great advisor this program for the motivation and all support so this program is successfully held.

\section{REFERENCES}

[1] Rosenberg, Robin S. and Andrea M.Letamendi, Expressions of Fandom.

[2] Pratiwi, R.S. 2014. Faktor Penyebab Perilaku Cosplayer Larp (Live Action Role Playing) Anime pada Komunitas Jceb (Japanese Club East Borneo) Samarinda. EJournal Psychology. Volume 2. Number 2: 217-226. Accessed on Feb 12, 2015

[3] Lamerichs, N. 2011. Stranger than fiction: Fan identity in cosplay. Maastricht University, Maastricht, The Netherlands. Transformative Works and Cultures. Vol 7. 